\title{
THE STATE, FAMILY LAW AND WOMEN IN THE MIDDLE EASTERN AND NORTH AFRICAN REGION (MENA REGION): A COMPARATIVE SURVEY OF THE CURRENT REFORMS IN MOROCCO AND TUNISIA
}

\begin{abstract}
Ashraf Booley ${ }^{1}$
ABSTRACT

Islam and codification of its family law in countries such as Morocco and Tunisia have taken on a somewhat of a different character depending on the specific setting in which it took place. Even though Islamic thought and in general Islamic law contains core principles observed throughout the Islamic world. Most aspects of Islamic law relating to the family originate in the divine text, while others may be found in customs of certain communities situated in different parts of the Muslim world. Some of the early reforms enacted by states such as Morocco and Tunisia have been hailed as victories for the rights of women especially where Islam is the dominant religion in those countries. A historical and comparative analysis relating to the rights of women reveal that this was not always the case. It may be argued that women rights were ancillary to the main agenda of those respective countries. Issues such as modernity, breaking the shackles of kinsman, classism and political alliances were deemed to be
\end{abstract}

1 Senior Lecturer, Private Law Department, University of the Western Cape, Cape Town, 7535, South Africa, abooley@uwc.ac.za 
high on the agenda of those countries. In Morocco and Tunisia, the state, early reformers and women's activism played and continues to play an important role or perhaps an indirect role in securing women-friendly rights in the family. In other Muslim jurisdictions, Islamic law has been left intact or very little change has occurred. The argument in those states is that Islamic law cannot be changed or re-interpreted. In this paper we investigate the reforms which have taken place in each country and why these countries have been hailed as being sensitive to the issue of women's rights. Although, these countries have been viewed as the vanguard of women friendly rights inequality does exist as new threats to the securing of women's rights are on the horizon.

Keywords: Islam, women, state, family law, Morocco, Tunisia, reforms

\section{INTRODUCTION}

Personal legal systems are various canons of law applicable to communities according to specific criteria, such as ethnicity and religious convictions. Generally, such legal systems are found to regulate matters in realm of the family (succession, inheritance and the determination of one's religious identity). Personal legal systems in countries such as Morocco and Tunisia may be considered as a legacy of colonialism. Personal legal systems in countries which were under the protectorate of the French are referred to as 'statut personnel' 2 , whereas, the term 'personal status' was used in countries which were colonised by the British. ${ }^{3}$ These terms have come to be associated with the family or family law in those colonised countries, as these terms govern significant issues covered by personal law legal systems. ${ }^{4}$ Morocco and Tunisia upon gaining independence embarked upon the codification of

2 Morocco and Tunisia were not colonies of the French only under the protectorate of the French. The Conventions of La Marsa, signed in 1883, by Bey Ali Muddat ibn al-Husayn, formally established the French Protectorate. It deprived the Bey of Tunisia control over internal matters by committing him to implement administrative, judicial, and financial reform dictated by the French. Tunisia became a protectorate of France by treaty rather than outright conquest, as was the case of Algeria. Tunisia - The protectorate (1881-1956), available at http://www. britannic.com, accessed on 10 November 2019.

3 Tagari, 'Personal Family Law Systems: A Comparative and International Human Rights Analysis,' International Journal of Law in Context (2012): 231.

4 There are different codes for different religions within Morocco and Tunisia, for example, Islam, Christianity and Judaism. 
its family law, ${ }^{5}$ adopted Codes of Personal Status in 1957-1958 and 1956, respectively. ${ }^{6}$ Although, western law replaced Islamic law in other areas, family law maintained its grounding in Islam. ${ }^{7}$ Religion in those countries (and others) occupy a central position within the family and in particular the individual, thereby acting as a buffer from western influences. ${ }^{8}$ The French refrained from interfering with the prevailing Islamic law, although other laws, such as those pertaining to contracts and property, were amended for economic and political reasons. ${ }^{9}$ The French were only too aware that any interference with Morocco's and Tunisia's family law could lead to social disorder, as Moroccan's and Tunisians viewed Islam as the cornerstone which both separated and distinguished their identity from the French. The result, Islamic family law in Morocco and Tunisia was left intact, serving as a point of differentiation between Tunisia, Morocco and France. Charrad, puts forward another reason, that of political expediency that the family law was untouched..$^{10} \mathrm{~A}$ further argument, could be that French saw no advantage of getting involved in the arena of the family, and left it untouched. Of recent, are the voices of those who are calling for reinforcement of various religious ideologies in other words returning to the pre-existing Islamic law. ${ }^{11}$ This article assesses the past and present reforms in women's rights in Morocco and Tunisia, within the framework of the family. It also briefly examines the states' role in the promulgation of women friendly rights within the context

5 Anderson, 'Modern Trends in Islam Legal Reform and Modernization in the Middle East,' International Law \& Comparative Law Quarterly (1971): 1-21.

6 Jansen, 'Muslim Brides and the Ghost of the Shari'a: Have the Recent Law Reforms in Egypt, Tunisia and Morocco Improved Women's Position in Marriage and Divorce and Can Religious Moderates Bring Reform and Make It Stick?' Northwestern Journal of International Human Rights, vol. 5/2 (2007): 181-212.

7 Jansen, 'Muslim Brides and the Ghost of the Shari'a: Have the Recent Law Reforms in Egypt, Tunisia and Morocco Improved Women's Position in Marriage and Divorce and Can Religious Moderates Bring Reform and Make It Stick?' 181212.

8 Jansen, 'Muslim Brides and the Ghost of the Shari'a: Have the Recent Law Reforms in Egypt, Tunisia and Morocco Improved Women's Position in Marriage and Divorce and Can Religious Moderates Bring Reform and Make It Stick?' 181212.

9 Charrad, 'State and Gender in the Maghrib,' Middle East Report (1990): 19-20.

10 Charrad, 'Family Law Reforms in the Arab World: Tunisia and Morocco,' (Report for the United Nations, Department of Economic and Social Affairs (UNDESA) Division for Social Policy and Development, Expert Group Meeting, New York, 15-17 May 2012), 1-14.

11 Charrad, 'Family Law Reforms in the Arab World: Tunisia and Morocco,' 1-14. 
of the family, thereby entrenching the most basic and fundamental rights of women. Morocco's past and present reforms will follow next.

\section{FAMILY LAW REFORM IN MOROCCO}

Morocco embarked upon codification of its family law early in the twentieth century. Prior to codification, Morocco's family law was primarily based on Islamic $1 \mathrm{aw}^{12}$ as interpreted by the dominant

12 Islamic jurisprudence (interchangeably called Islamic law or Shariah) has a fairly well-defined structure and textbooks relating to it and invariably deal with a range of familiar topics, for instance the family. Islamic jurisprudence is primarily concerned with the manner in laws are derived from the Qur'ann and Sunnah (the precedent of Prophet Muhammad [PBUH]. Islamic law, Shariah, or jurisprudence is essentially the interpretation and application of the primary sources by early Muslim male jurists like Imams Abū Ḥanīfah and Shāfi' $\overline{1}$. Some of the greatest Muslim philosophers, such as Ibn Sina, Ibn Rushd and Al-Ghazali, wrote treaties, not only on Islamic legal philosophy, but also on substantive law issues such as Islamic family law. The profound difference, perhaps, between Islamic jurisprudence and Western jurisprudence is the fact that morality and religion acquire much greater prominence in Islamic jurisprudence. Kamali explains: "The values that must be upheld and defended by law and society in Islam are not always validated on rationalist grounds alone. Notwithstanding the fact that human reason always played an important role in the development of Shariah through the medium of ijtihäd (personal reasoning), the Shariah itself is primarily founded on divine revelation". Fiqh is the science of Muslim jurisprudence. Very often scholars use the term Shariah (Islamic law) in a technical sense to denote the law as found in primary sources. These scholars then use the term fiqh to describe the Islamic jurisprudence as developed from these primary sources. There are also scholars who use the terms Shariah and fiqh synonymously. There are other scholars who reserve the term fiqh for Islamic law and usül al-fiqh (principles of science of Islamic jurisprudence) to denote Islamic jurisprudence. Moosa, 'A Comparative Study of the South African and Islamic Law of Succession and Matrimonial Property with Special Attention to the Implications for Muslim Women,' (Master Dissertation, Faculty of Law, University of the Western Cape, Bellville, 1991), 1-12. 
Mālik $\overline{1}^{13}$ religious school of thought. ${ }^{14}$

In 1956, Morocco gained independence from France with Spain relinquishing most of its authority during the same period. ${ }^{15}$ Family law reform were first embarked upon in 1957 and 1958 respectively, when a special commission was mandated to draft the Code of Personal Status referred to as the mudawana. ${ }^{16}$ The commission comprised ten male religious scholars drawn from the Mālikī religious school of thought, the Minister of Justice and the monarchy. ${ }^{17}$ Sadly, no women served on the commission which dealt with formulation of the mudawana, which directly relates to the family.

Therefore, the formulation of the mudawana, could be viewed as ecclesiastical, male oriented and perhaps the most important initiative by the monarchy and the Moroccan government since independence relating

13 About 90 percent of Muslim globally are referred to as Sunni or Sunnites. Sunni Islam is essentially divided into four dominant religious schools of thought or Sunni jurisprudence that emerged, since the passing of Prophet Mohammed [PBUH]. They are referred to as the Hanafī, Mālikī, Shāfi'ī and Hanbalī schools (madhhab/s meaning school/s or the path or way followed). The names of the schools refer to the names of the leading scholars Abū Hanīfah, Malik ibn Anas, Muhammad ibn Idris al-Shāfi' $\overline{1}$ and Ahmad ibn Hanbāl. The four dominant religious schools of thought are placed on equal footing and Muslims may choose amongst them. There are several sources of Islamic law. The Qur'an and the sunnah are the primary sources, whereas ijmá', qiyās or ijtihād and 'urf(custom) are referred as secondary sources. There are two dominant sects found in Islam, namely, the Sunni and Shi'ah. There is also the Shia sect found in Islam. The Shia sect is a separate sect which broke away from the Sunni sect, following the succession controversy which arose after the passing of Mohammad. A comprehensive discussion relating to the various sects and religious schools of thought, is beyond the scope of this article. Ur-Rahman A, Code of Muslim Personal Law, vol. 1 (Karachi: Islamic Publishers, 1984), 1-5.

14 Charrad, 'Family Law Reforms in the Arab World: Tunisia and Morocco,' 1-14.

15 Zoglin, 'Morocco's Family Code: Improving Equality for Women,' Human Rights Quarterly, vol. 31/4 (2009): 964-984.

16 Jansen, 'Muslim Brides and the Ghost of the Shari'a: Have the Recent Law Reforms in Egypt, Tunisia and Morocco Improved Women's Position in Marriage and Divorce and Can Religious Moderates Bring Reform and Make It Stick?' 181212. The term mudawana will be used instead of the Code of Personal Status in this article to distinguish it from Tunisia.

17 Jansen, 'Muslim Brides and the Ghost of the Shari'a: Have the Recent Law Reforms in Egypt, Tunisia and Morocco Improved Women's Position in Marriage and Divorce and Can Religious Moderates Bring Reform and Make It Stick?' 181212 . 
to the family. Integrating under one set of family laws the ethnic and tribal groups (as it was then) in Morocco, the mudawana has become a symbol of both national unity and Islamic identity, entrenching the significance of the monarchy and the Mālikī religious school of thought. ${ }^{18}$ The mudawana relates to the family, and as such regulates, amongst other issues, marriage, polygamy, divorce, inheritance, maintenance and child custody. ${ }^{19}$ It could be argued that the mudawana determines the status of Moroccan women throughout her life, commencing at birth and including her capacity to own, inherit and to manage property, her freedom to work, marriage and perhaps her remarriage, as well as her relationship with her children. ${ }^{20}$ The 1950 's version of the mudawana, a woman was considered to be a minor under the guardianship of her father and thereafter the husband, or other male guardian within the context of the immediate family (in some instances it could include her brother which could perhaps be younger than her). ${ }^{21}$ In close alliance to the Mālikî religious school of thought, dominant sections of the mudawana address the right to compel a daughter to marry (if a female contracts her own marriage it is in every respect void, this is also the view of the Shāfi' 1 religious school of thought), ${ }^{22}$ the minimum age for marriage (fifteen years for girls and eighteen years for boys). Marriageable age in Islam, coincides with the occurrence of puberty. ${ }^{23}$ Puberty refers to signs of physical maturity such as the emission of semen for males, and the onset of menstruation for females. ${ }^{24}$ It does speak to the emotional maturity of the parties. Inferences may be drawn from the above that physical maturity coincides with emotional maturity, which does not coincide with each other. The husband has the right of unilateral right of repudiation (divorce,

18 Charrad, 'Family Law Reforms in the Arab World: Tunisia and Morocco,' 1-14.

19 Jansen, 'Muslim Brides and the Ghost of the Shari'a: Have the Recent Law Reforms in Egypt, Tunisia and Morocco Improved Women's Position in Marriage and Divorce and Can Religious Moderates Bring Reform and Make It Stick?' 181212.

20 Ur-Rahman A, Code of Muslim Personal Law: Validity of Marriage (Nikah), vol. 3, 42-43.

21 Htun \& Weldon, 'State Power, Religion And Women's Rights: A Comparative Analysis of Family Law,' International Journal of Global Legal Studies (2011): 145-165.

22 Ur-Rahman A, Code of Muslim Personal Law: Validity of Marriage (Nikah), vol. 3, 38-39.

23 Büchler \& Schlatter, 'Marriage Age in Islam and Contemporary Muslim Family Laws: A Comparative Survey,' Electronic Journal of Islamic and Middle Eastern Law, vol. 1 (2013): 37-74.

24 Büchler \& Schlatter, 'Marriage Age in Islam and Contemporary Muslim Family Laws: A Comparative Survey,' 37-74. 
including the practice of polygamy) and judicial divorce at the request of the wife based upon specific reasons as determined by the Mālikī religious school of thought ${ }^{25}$, for example, lack of maintenance and harm. ${ }^{26}$ It could be argued strongly, that male supremacy was concretized in terms of the 1950's version of the mudawana as the husband was seen as the head of the family and as its provider. ${ }^{27}$ This places the wife in a very vulnerable situation. The woman whether wife or daughter has no option but to depend on the male/s in the family for all their needs, whether financially or other. This has the effect of strengthening the patriarchal culture, which has characterised the past and still unfortunately the present.

Although there have been reforms, none have been as forward thinking than the reforms which took place in 2004. Various political and religious events contributed to making women more visible in Moroccan society and these, in turn, impacted on the formulation of the reformed mudawana. This included a public speech in August 1993 by Amina Mrini to mark the inauguration of the Mosque Hassan II in Casablanca. ${ }^{28}$ The public role assumed by the wife of King Mohamed VI, especially during their wedding in 2002, the introduction of a quota system for women representatives in parliament in 2002, an increase in women's associations and non-governmental organisations with a focus on promoting women's rights, such as reproductive health, assisting victims of violence, ${ }^{29}$ and the formulation of a plan for the integration of women in sustainable human development with a view to combating socio-cultural prejudices and attitudes. Inferences could be drawn that one of the driving forces behind the development of the mudawana was the Monarchy, however, other driving forces must also be highlighted..$^{30}$ These could include NGO's, women's organizations and perhaps international political pressure. The process of reform, undertaken by King Mohamed VI's father King Hassan II

25 Ur-Rahman A, Code of Muslim Personal Law: Validity of Marriage (Nikah), vol. 3, 42-43.

26 Charrad, 'Family Law Reforms in the Arab World: Tunisia and Morocco,' 1-14.

27 Repeated calls were made for the reform of the mudawana. Attempts at reform followed in 1961, 1962 and 1965 respectively, with the establishment of an official commission to examine any shortcomings in the mudawana, and similar attempts were made throughout the 1970's.

28 Htun \& Weldon, 'State Power, Religion And Women's Rights: A Comparative Analysis of Family Law,' 145.

29 Campbell, 'Morocco in Transition: Overcoming the Democratic and Human Rights Legacy of King Hassan II,' Journal of Democracy, vol. 23/1 (2012): 38-42.

30 Bordat \& Kouzi, 'The Challenge of Implementing Morocco's New Personal Status Law,' 2 Arab Reform Bulletin 8 (2004), available at www.ceip.org/arabreform, accessed on 20 May 2019. 
in the 1990's, was given a jolt by the bomb attacks in Casablanca in 2003. ${ }^{31}$ As a result of the attack as well as other factors, such as unrest in certain geographical areas. King Mohamed VI, delivered a speech to the Moroccan parliament in which he demonstrated his will to present an alternative version of the mudawana so called radical Islam which related to the events that took place in Casablanca. ${ }^{32}$ The King's speech linked the mudawana, and the Quranic verses, with it's compatibility with Islamic law. Also, the King made it crystal clear that his authority was supreme, and that parliament should not be an obstacle in the promulgation of the new reformed mudawana. ${ }^{33}$

The mudawana proceeds with a preamble which provides an overview of much of the reasoning as well as policy considerations that accompanied the King's speech which was delivered before parliament. ${ }^{34}$ The King's speech included the following; 1) the adoption of a modern form or wording and the removal of degrading and debasing terms relating to women, 2) the freedom of women to arrange their own marriage thereby eradicating the mandatory supervision of a guardian or wali, 3) equality between men and women relating to the minimum age for marriage, 4) allowing the practice of polygamy under strict restrictions, 5) the simplification of marriage procedures for Moroccans living abroad, 6) making divorce equally available to both women and men, 7) the expansion of a women's right to divorce when the husband does not abide by the conditions stipulated in the marital contract, 8) the protection of the child or children's interest relating to custody issues, 9) the acknowledgement of paternity of children born outside the sphere of registered marriages, 10) equality in relating to inheritance and 11) the possibility to make arrangements for property acquired during the subsistence of the marriage. ${ }^{35}$

Under the 2004 mudawana, the family is now the joint responsibility of both spouses, while under the previous law, the family was the sole responsibility of the husband alone. ${ }^{36}$ It included full financial responsibility. In return, the

31 Maddy-Weitzman, 'Women, Islam and the Moroccan State: The Struggle over the Personal Status Law,' Middle Eastern Journal, vol. 59 (2005): 396-397.

32 King Mohamed VI, 'Speech at the Opening of the Parliament Fall Session,' 10 October 2003 available at http://www.mincom.gov/ma, accessed on 19 May 2019.

33 "As the King of all Moroccans, I do not make legislation for a given segment of the population or a specific party. Rather, I seek to reflect the general will of the nation, which I consider my extended family"

34 Prettitore, 'Family Law Reform, Gender Equality, and Underage Marriage: A View from Morocco and Jordan,' The Review of Faith \& International Affairs, vol. 13/3 (2015): 32-33.

35 Moroccan Family Code of 2004.

36 Charrad, 'Family Law Reforms in the Arab World: Tunisia and Morocco,' 1-14. 
wife was held to obey her husband..$^{37}$ The 2004 reformed mudawana removed the obedience of the wife and stated the wife must now also contribute to the household expenses. ${ }^{38}$ It could be argued, that this amendment echoes the essence of Muhammed, who, upon delivering his farewell sermon near Mount Arafat, instructed: "[ $\mathrm{t}]$ reat your women well and be kind to them for they are your partners and committed helpers". ${ }^{39}$ A wife can no longer request a divorce based on a lack of financial support if she is by the means to support herself and her husband, who has no financial means. ${ }^{40}$ The conclusion of her marital contract by anyone else is something the woman had to delegate expressly. As opposed to the previous law, under which a woman needed the consent of her guardian, the new law states that marriage tutelage is the right of the woman, which she exercises upon reaching the age of majority according to her choice and interest. ${ }^{41} \mathrm{~A}$ distinct difference between the two countries, is that in Tunisia, a medical certificate is required before the parties conclude the marital contract. As is the case in Tunisia, a medical certificate is mandatory to prevent venereal or sexually transmitted contagious diseases..$^{42}$ In addition, the medical certificate can also protect the physical, emotional and well-being the parties and their offspring. This ties in with the well- being of the child, which has become very important in this time, where international human rights treaties have been concluded to protect the rights of the child.

Polygamy is outlawed when there is a risk of inequity between the wives. ${ }^{43}$ Authorization from the court is needed (Islamic courts) and could be turned down if there is an exceptional justification that is not proven or if the husband does not possess the resources (referring to financial resources) to support both families. ${ }^{44}$ The husband must petition the court, and his first wife must be informed and invited to attend such proceedings. ${ }^{45}$ Should the court grant permission to the husband to contract a second marriage, it will not proceed until

\footnotetext{
37 Charrad, 'Family Law Reforms in the Arab World: Tunisia and Morocco,' 1-14.

38 Charrad, 'Family Law Reforms in the Arab World: Tunisia and Morocco,' 1-14.

39 Warren, 'Lifting the Veil: Women and Islamic Law,' Cordoza Journal of Law and Gender, vol. 15 (2008): 33-65.

40 Moroccan Family Code of 2004, article 188.

41 Moroccan Family Code of 2004, article 24.

42 'Arab Reporters for Investigative Journalism ARIJ,' available at http://en.arij.net, accessed on 20 May 2019.

43 Moroccan Family Code of 2004, article 40.

44 Moroccan Family Code of 2004, article 41.

45 Moroccan Family Code of 2004, article 44.
} 
the future wife is informed that her prospective husband is already married..$^{46}$ In the event that the current is not satisfied, with her husband, entering into a second marriage the existing wife may institute divorce proceedings and the court can award her compensation in the form of money. ${ }^{47}$ The previous law did not include the intervention of the court. However, the husband is required to inform his wife of his decision to contract a further marriage as well as to inform the future wife that he is already married..$^{48}$ These reforms now gives the wife the option, which she did not possess in the past, to make an informed decision, whether or not to accept. This is to be welcomed, as the past has shown that it is always the women and children that suffer the most. This could include a range of suffering, such as, emotional, financial and psychological effects, which in many instances is lasting on the wife and child/children. ${ }^{49}$

Repudiation (tala $q$ ) is now made conditional upon the consent of the national courts. ${ }^{50}$ Under the previous law, the husband could repudiate the wife without judicial intervention at a national level and at any time, as he chose. The current procedure is that if the husband wants to institute divorce $(t a l \bar{a} q)$ proceedings, he must pay all monies owed to the wife, including any dower (mahr) whether prompt or deferred, maintenance for or during the waiting period (iddah in such circumstances in three months under other circumstances it could be longer if the wife is found to be pregnant) as well as a consolation gift ${ }^{51}$, which is assessed on the bases of the duration of the marriage, the financial position of the husband, the reason for the repudiation and the extent to which the husband abused his right are factors taken into account. ${ }^{52}$ The wife during the waiting period (iddah) is to reside in the marital home or other suitable accommodation to be provided by the husband. If this not forthcoming the court determines a fixed sum to cover housing expenses..$^{53}$ This procedure is to be welcomed, because in most instances the wife and children are left homeless. Worst case scenario, the wife and children will have to take refuge with her own family (usually her parents), which may in turn prove not to be the best alternative. There may be already overcrowding in

\footnotetext{
46 Moroccan Family Code of 2004, article 46.

47 Moroccan Family Code of 2004, article 45.

48 Charrad, 'Tunisia at the Forefront of the Arab World: Two Waves of Gender Legislation,' Washington \& Lee Law Review (2007): 1513-1527.

49 Studies have been undertaken to establish the effects, however, a comprehensive discussion relating to those effects is beyond the scope of this paper.

50 Moroccan Family Code of 2004, article 79.

51 Yusuf Ali

52 Moroccan Family Code of 2004, article 84.

53 Moroccan Family Code of 2004, article 84.
} 
the parent's home and perhaps a lack of financial resources. This could have a detrimental effect on the wife and her children, which in turn would put them in a vulnerable situation, having to make do with what is available.

Either spouse or both spouses together may petition the court for divorce on the grounds of irreconcilable differences. ${ }^{54}$ This provision ties in with the Western type of divorce currently found in some Western jurisdictions, where the parties could institute divorce proceedings based on irreconcilable differences. Divorce by mutual consent under the auspices of the courts did not exist in the previous law. ${ }^{55}$ A reconciliation procedure should be undertaken by at least two arbitrators or by two other persons able to deal with the reconciliation. However, divorce proceedings must be concluded within six months once the divorce petition has been filed with the court. ${ }^{56}$ The effect is that the wife is not kept hanging or put in a state of limbo. Another advantage, is that proceedings do not carry on indefinitely, prolonging the separation on the parties, which could result in injuring each other's personality and the children.

Under the previous law wife could only petition for divorce on limited grounds, such as harm caused by the husband which was challenging to prove in court, not providing maintenance by the husband, absence of the husband for more than a year in an unknown location and without valid justification, or an oath of abstinence taken by the husband. ${ }^{57}$ Another option would be to buy her freedom by returning (part) of the dower or by some other means of compensation (also referred to as a Khul divorce). ${ }^{58}$ The new family law allows the petition for divorce also if the husband does not comply with any condition in the marital contract, ${ }^{59}$ failure to comply with any of the conditions listed in the marital contract is considered to constitute harm that justifies divorce proceedings.$^{60}$ Harm can be established by any means of proof and if the wife is unsuccessful in obtaining such proof, she can resort to irreconcilable differences as a ground to establish divorce proceedings. ${ }^{61}$ Finally, a substantive feature relating to the issue of custody is that under certain circumstances a

\footnotetext{
54 Moroccan Family Code of 2004, article 94

55 Anderson, 'Reforms in Family Law in Morocco,' Journal of African Law (1958): 146-159.

56 Moroccan Family Law of 2004, articles 95, 96 and 97.

57 Anderson, 'Reforms in Family Law in Morocco,' 146-159.

58 Anderson, 'Reforms in Family Law in Morocco,' 146-159.

59 Moroccan Family Code of 2004, article 98.

60 Moroccan Family Code of 2004, article 98.

61 Moroccan Family Code of 2004, article 100.
} 
woman can or may retain custody of the child or children if she remarries or moves away from the area where her former husband resides. ${ }^{62}$ Child custody is exercised irrespective of gender until the child or children attain the age of legal majority. ${ }^{63}$ Also, it is stipulated explicitly that children should receive suitable accommodation, consistent with living conditions when the parties were husband and wife. ${ }^{64}$ It must not be confused with maintenance arrangements, which is a separate arrangement. ${ }^{65}$

In summing up the position of the new family law in Morocco, it is progressive in which women have more rights when it comes to marriage and divorce. The reforms to the mudawana can perhaps also been viewed as aligning itself with international human right treaties which the Morocco has ratified and now implementing at a national level. However, inequality still exists in many spheres of the Moroccan society, for example certain traditional patriarchal structures and the judiciary which seems to be still implementing past family laws. Of concern, is the fact many rural women are not aware of the new law which give them more rights than before. There is much to do, to spread the message of the new mudawana at grassroots level. Tunisia's past and present family law reforms follow next.

\section{FAMILY LAW REFORM IN TUNISIA}

Modern-day Tunisia was under the French protectorate from 1881 until $1956^{66}$ and, together with Algeria and Morocco, these states share a sense of solidarity in their relationship with France, a foreign and a non-Muslim state. ${ }^{67}$ The particular practice of Islam developed in Tunisian society was very similar to Morocco, based on kin groupings that allowed male members of the group to have almost complete control over the status of women. ${ }^{68}$ Islamic law as interpreted by the more dominant Mālikī and less Hanafî religious schools of

\footnotetext{
Moroccan Family Code of 2004, articles 174, 175 and 178.

Moroccan Family Code of 2004, article 166.

64 Moroccan Family Code of 2004, article 171.

65 Moroccan Family Code of 2004, article 168.

66 Angrist, 'The Expression of Political Dissent in the Middle East: Turkish Democratization and Authoritarian Continuity in Tunisia,' Comparative Studies in Society and History (1999): 730-748.

67 In 1953, the Moroccan Sultan was deposed, an event that stirred religious sentiments and a sense of solidarity in both Algeria and Tunisia.

68 Control could be from birth into adulthood as well married life.
} 
thought, was particularly evident of this type of control. ${ }^{69}$ These two religious schools of thought also sanctioned a special bond, especially amongst the male members of the extended kin group..$^{70}$ The combined power of the husband and male kin over women's lives, referred to by Charrad as "kin-based patriarchy", ${ }^{71}$ represented a particular form of subordination and control that women experienced, not only in Tunisia, but also in most Arab and Middle Eastern countries. ${ }^{72}$

Some of these practices included adherence to all restrictions impacting on the legal status of women. ${ }^{73}$ There was no minimum age for marriage,

${ }^{69}$ Charrad, 'Tunisia at the Forefront of the Arab World: Two Waves of Gender Legislation,' 1513-1527. According to Charrad, the Mālikī school of thought is applied to the overwhelming majority of Muslims in Tunisia.

70 Before independence, the Tunisian society was formed on the concept of the family and the relied on the tenets of tribalism and classism, to the point in which governing bodies were instituted along those tenets. "The traditional Tunisian family was socially 'central' in so far as the greater part of social dynamics were centred on it. Objectively, the major articulations of society were the lineages. The state was formed by one of these lineages, and the group tended to be organized like a family. For the individual, the family was the group, which he owed his life, his identity, and his social legitimacy it was the outlet for his needs and the mediator, if not the sphere of application, of his values. On the symbolic level, it appeared as the most plausible model of social relationships 'patriarchalism' thus became a form of social relations going far beyond the domestic institutions from which it derived its name. In this way, when the individual considered the world outside his domestic group, everything referred him back to the family and to his family" according to Camelleri. See Camelleri, 'Modernity and the Tunisian Family in Tunisia,' Journal of Marriage and the Family (1967): 590-595.

71 Buskens, 'Recent Debates on Family Law Reform in Morocco: Islamic Law as Politics in an Emerging Public Sphere,' Islamic Law and Society (2003): 70-75.

72 In general, the principles of the ruling or elite families were to all Tunisian's marriage enabled the concretising of social ties and helped to meet the needs of the family as a whole, couples had no voice in choosing their partners. Camelleri, 'Modernity and the Tunisian Family in Tunisia,' 590-595.

73 Charrad, 'State and Gender in the Maghrib,' 19-20. During the colonial period, women were marginalized and secluded, little or no access to education, economic activity was confined to the household, the wearing of the veil was considered the norm and very little activity in public life. These conditions were considered as Tunisian culture and representing the type of Islam found in Tunisia. 
except for the stipulation that marriage should take place after puberty. ${ }^{74}$ The actual ceremony that confirmed the marital contract had to be attended by the father, or in his absence the male guardian ${ }^{75}$, who uttered the consent to the marriage because in most instances the bride was not present. ${ }^{76}$ Omri, a legal scholar, argues that a person steeped in European culture or perhaps belonging to another faith, the thought of marriage in absentia, without approval from the bride, is absurd. The Western idea of marriage is that the bride is always present, this unfortunately does not take in account the traditions or the laws of non-Western countries, thereby creating a stereotypical view of what marriage ought to be, instead of how it is practice in other geographical areas. However, such marriages were common well before the codification of family law in the MENA region. ${ }^{77}$

Islam did not introduce polygamy nor was it part of an Islamic phenomenon. ${ }^{78}$ Therefore, in pre-independent Tunisia, polygamy was allowed, and the husband could be married to as many as four wives at a time. ${ }^{79}$ Although in

74 Yusuf Ali A., The Holy Quran: Text, Translations and Commentary (Lahore: Ashraf Press, 1938), Chapter IV, verse 6. A girl is considered an adult when she starts to menstruate. There exists a presumption in Islam that puberty may be reached at fifteen years of age, but evidence can be deduced that it may be reached sooner. The minimum age would appear to be twelve years for boys and as early as nine years for girls.

75 One of the problems directly connected with the conditions of marriage is marriage guardianship or wilayat al-nikah. Simply put, marriage guardianship is the legal authority vested in a person who is fully qualified and competent to safeguard the interest and rights of another who is incapable of doing so independently. It is usually the authority of a father or nearest male relative over the following person, namely, minors, mentally challenged or person without experience who need protection and guardianship. On the other hand, a legal representative or wakil, is a person who has agreed through private arrangements, to represent another party within the limits of authority delegated to him by the principle party. Such delegated authority may include arrangements of marriage subject to the approval of the principle party, in some instances, the guardian.

76 Yusuf Ali A., The Holy Quran: Text, Translations and Commentary, Chapter IV, verse 6.

77 Omri, 'Women and Marriage in Secular Islamic Country,' Journal of Policy Studies (2005): 91-93.

78 Polygyny was exercised by Babylonians, Greeks, Persians, and Arabs. Furthermore, many pre-Islamic religions for example, Judaism accepted polygamy amongst its practices.

79 Yusuf Ali A., The Holy Quran: Text, Translations and Commentary, Chapter IV, verse $6,134$. 
reality, only a small minority of men could afford to have more than one wife at a time. ${ }^{80}$ The justification for allowing the practice was found in the Qur'an and the sunnah of Islam. ${ }^{81}$ Although, only a few engaged in polygamy, it could be argued that that the legality of polygamy had the potential of threatening women and pressured them into compliance with the husband's demands. There could have been other factors that could have the same effect, for example, socio-economic reasons, no matter what the reasons, polygamy was and is perhaps today still an obstacle for women to achieve true equality. It was the practice of most Muslim states at that time although the practice of polygyny continues in a few Muslim states today. ${ }^{82}$ Sometimes polygamy is practiced in secret in both urban and rural areas and not registered or reported, therefore one cannot argue that polygamy is not practiced.

In terms of the dominant religious school of thought, being the Mālikī school, repudiation by the husband required only the presence of two witnesses (only males witnesses females were excluded as witnesses) and no judicial intervention was required ${ }^{83}$ Furthermore, the wife had no judicial recourse at a national level only a religious level. ${ }^{84}$ According to Charrad, another recourse the wife had was to turn to her family or community to approach the husband to request that he does not repudiate her. ${ }^{85}$ This would only apply to women and not men, thereby diminishing the dignity of women and placing them at the mercy of the family. Without national judicial intervention, the wife was in a vulnerable situation as there was no protection for her wellbeing or her children. However, women could appeal to a religious judge and ask for a divorce. It could only be accomplished on highly limited grounds and was extremely difficult, according to Charrad. ${ }^{86}$ According to the Mālikî religious school of thought, a wife could get a judicial divorce for abandonment and lack of financial and material support, including specific categories of harm

80 Charrad, 'State and Gender in the Maghrib,' 19-20.

81 Yusuf Ali A., The Holy Quran: Text, Translations and Commentary, Chapter IV, verse 3, 134.

82 Western, 'Islamic Purse Strings: The Key to the Amelioration of Women's Legal Rights in the Middle East,' Air Force Law Review (2008): 79-147.

83 Charrad, 'Tunisia at the Forefront of the Arab World: Two Waves of Gender Legislation,' 1513-1527.

84 Charrad, 'Tunisia at the Forefront of the Arab World: Two Waves of Gender Legislation,' 1513-1527.

85 Charrad, 'Tunisia at the Forefront of the Arab World: Two Waves of Gender Legislation,' 1513-1527.

86 Charrad, 'Tunisia at the Forefront of the Arab World: Two Waves of Gender Legislation,' 1513-1527. 
and injury ${ }^{87}$ According to Haddad's book, the "Imra'atuna fā al-Sharī'ah wa al-Mujtamā'" (Our Women in the Sharia and in Society) provides a lonely picture of the situation of women in Tunisia, which was drawn from the author's experiences when he visited the religious court's in Tunisia. Haddad states; "I went in person to our Shariah courts to ascertain if there was statistical data telling about marriages and divorces and I found that they did not exist". 88 Within Tunisia there existed two types of courts, namely, the secular courts and the Shariah/religious courts. These courts adjudicated on different issues. The secular court would, for example, only deal with civil issues, whereas the Shariah/religious courts would constrain itself with the issue of family law. Inferences could come from Hadadd's account that the Shariah/religious courts we not well organized and staffed as compared to secular courts. In Tunisia, Haddad, was one of many early reformers, which included Mohamed Abdu and Qasim Amin, who frequently lectured about the rights of women within an Islamic context. Qasim Amin published books titled The Liberation of Women and The New Woman, which many points as a departure in Egypt concerning the status of women. ${ }^{89}$ In these works he advocates the emancipation of women as a vital step in the modernization of the Middle Eastern and North African countries, which needed the support it would receive from providing women access to education and socio-economic opportunities. ${ }^{90}$

After the death of Haddad in $1935^{91}$, the feminist movement was taken over by Habib Bourguiba, a lawyer and included partisans of the New Constitutional Liberal political party (referred to as Neo Destour political party) ${ }^{92}$, becoming

87 Stilt \& Gandhavadi, 'Strategies of Muslim Family Law Reform,' (Faculty Working Papers, Northwestern University School of Law Scholarly Commons, 2011), 1-34.

88 Khedher, 'Tracing the Development of the Tunisian 1956 Code of Personal Status,' Journal of International Women's Studies, vol. 18/4 (2017): 31.

89 Booley, 'Progressive Realisation of Muslim Family Law: The Case of Tunisia,' PELJ (2019): 1-22.

90 Khedher, 'Tracing the Development of the Tunisian 1956 Code of Personal Status,' 31-34.

91 Changes to society cam slowly before, independence, but voices to alter gender roles and existing marriage norms did exist.

92 Neo Destour did not reject Islam it was considered a secular movement with fewer religious ties than preceding independent parties because leaders of the newer parties were more influenced by the French Enlightenment thinkers owing to a French education. In addition, Neo Destour was more Westernized and supported Tunisia becoming a republic. 
an integrated and unified national struggle against the French. ${ }^{93}$ The alliance between leading factions of the nationalist movement erupted as the French were pushed out of Tunisia in the mid-1950s. During this period a conflict ensued between two major nationalist factions, on the one hand a group supporting modernization and on the other hand, a group holding on to the traditional on the precipice of independence from the French. ${ }^{94}$ Suffice to say that these factions had contrasting views relating to the Islamic establishment and kin-based groupings. In addition, these factions differed in establishing certain projects for Tunisia. Bouguiba's faction was the ultimate winner and drew its constituents from the urban areas and the backing of the workers union. The competing faction, led by Ben Youseff found support amongst the kin-based communities in rural areas including the members of the religious establishment. ${ }^{95}$ As the conflict intensified, Bourguiba, convinced the French to assist, which they agreed as the colonial rule was eroding sharply, the French preferred a sovereign Tunisia under the leadership of Bourguiba than that of Ben Youseff. ${ }^{96}$ The Tunisian nationalist movement ended with the termination of the French Protectorate and the realization of Tunisian independence on March 20 1956, with no surprise as Bourguiba as its first president. ${ }^{97}$

The issue of gender equality within a Tunisian context has been underway for some time, albeit, with little or no substantial progress. It was only after the aftermath of independence from the French that Bourguiba came to make substantial changes within family law, through the Code of Personal Status in 1956.98 The Code of Personal Status (referred to as the Majallat al-Shakhșiyyah) (which will be referred to as the CPS) enacted only six months after independence and considered as a monumental step towards the

93 Upon the founding of the Neo Destour party in 1934 the final chapter of Tunisian nationalism started. Bourguiba and his Neo Destour members belonged to an elite group of intellectual elites whose modest background helped them to identify with the masses and whose Western education assisted them to fight the French on their own ground.

94 Anderson, 'Reforms in Family Law in Morocco,' 146-159.

95 Charrad, 'Policy Shifts: State, Islam, and Gender in Tunisia, 1930s-1990s,' Social Politics, vol. 4/2 (1997): 284-319.

96 Charrad, 'Policy Shifts: State, Islam, and Gender in Tunisia, 1930s-1990s,' 284319.

97 McCarthy, 'Re-thinking Securalism in post-independence Tunisia,' The Journal of North African Studies, vol. 19/5 (2014): 737.

98 Weideman, 'Tahar Haddad After Bourguiba and Bin Ali: A Reformist between Seuclarists and Islamistst,' International Journal Middle Eastern Studies, vol. 48 (2016): 47-65. 
modernization of Tunisia. ${ }^{99}$ The CPS was introduced as law, on the January $1^{\text {st }} 1957$, and represented a forward-thinking reform from above, attached to the executive branch. ${ }^{100}$ The approach was from a top-down reform, instead of the more traditional bottom-up reform. Although, the CPS involve lawyers and religious leaders there seems to be no involvement of women in the drafting process. This seems to at odds with the realization that the gender issue has been going for decades within Tunisia by various jurists, such as Haddad, Mohamed Abdu and Qasim Amin. The CPS was considered as being complementary to the larger state building programme that was pivoted towards a modern centralized state as well as diffusing tribal or kin-based communities in the rural areas. ${ }^{101}$ The CPS was part of the so called "the war against underdevelopment" this included amongst others, the lamination of the government deemed as impediments to the creation of the modern state. Such impediments could include kin-based corporate communities and patriarchal arrangements permitted by the Shariah, which was deemed as hampering the process of nation building. ${ }^{102}$ Although the Islamic faith dominates Tunisia, Bourguiba has continuously defended Tunisia's Islamic legacy by stating that

99 After the separation of Tunisia from the Ottoman Empire, some lawyers in the country started to contemplate a uniform family code based on the dominant scholl of thought, the Mālikī school. These lawyers were inspired by the codification and reform of family law taking place in Egypt, the Sudan, Jordan as well as Syria. The theologian jurists at that time unofficially prepared a monograph setting in parallel columns the corresponding provisions of the Mālikī and Hanafĩ schools relating to the various legal matters including family law. This monograph was referred to as Lā ihā t al-Majallat al-Ahkām al-Shar 'iyyah (draft code of the law of Shariah). Subsequently, another draft code was officially prepared on similar lines, by the Shaykh al-Islam of Tunisia Muhammad Ju'ayt, with the assistance of a committee of some of the leading lawyers in Tunisa.The CPS was established as a Presidential Decree and assembled under the Ministry of Justice becoming law on January 1, 1957.

100 Charrad, 'Policy Shifts: State, Islam, and Gender in Tunisia, 1930s-1990s,' 284319.

101 Charrad, 'Tunisia at the Forefront of the Arab World: Two Waves of Gender Legislation,' 1513-1527.

102 Charrad, 'Policy Shifts: State, Islam, and Gender in Tunisia, 1930s-1990s,' 284319. In speech delivered by Bourguiba relating to marriage as well as consent, he stated: "It is inadmissible, I am sorry to say, that parents constrain their son to marry a young woman chosen for their convenience. We have in this respect strange practices. There are the young women who have been 'promised' to a young man for a long time. There are the female cousins, the female relatives with various degrees of kinship closeness, a whole series of young women to marry off... Let's leave the decision to the husband and wife to be". 
CPS is based on the more dominant Mālikī and lesser Hanafì religious school of thought or the part that relates to family law. The CPS does not change was is halal (permissible) or haram (not permissible) but is complementary to the Tunisian social life. ${ }^{103}$ Scholars such as Weideman and Ganna, when addressing the CPS and in particular the spirit they argue it is unmatched in the Muslim world except perhaps historically Turkey. The CPS did not altogether abolish the Shariah law, nor did it proceed to mimic the European model under the leadership of Ataturk. ${ }^{104}$

Book 1 addresses the requirements of marriage to be deemed valid. Of importance is that the consent must be obtained by both parties to the marriage, in front of two worthy witnesses as well as dower (mahr) payable to the wife be specified. ${ }^{105}$ The CPS put an end to the popular practice of arranged and perhaps forced marriages that could have existed during the period of colonialism. Although, the practice of arranged and forced marriages could take place privately without the authorities being made aware. ${ }^{106}$ The CPS prevents arranged and forced by taking away the authority of the father and/ or guardian which could perpetuate the abovementioned practices. ${ }^{107}$ The introduction of the CPS made the marriage a voluntary and consensual union, and the courts had the authority to end it. ${ }^{108}$ The CPS at that time required that the parties must be of a certain age which for females was 15 years old and for males 18 years. In addition, the marriage of either party below the legislated age shall be subject to the special authorization by the courts. The authorization shall only be given upon proof of the attainment on physical maturity and as Morocco ignores the emotional maturity of the parties, in this instances the female. ${ }^{109}$ Furthermore, the difference of age within the CPS could constitute a distortion relating to the bargaining power and could result

103 Khedher, 'Tracing the Development of the Tunisian 1956 Code of Personal Status,' 30-37.

104 Weideman, 'Tahar Haddad After Bourguiba and Bin Ali: A Reformist between Seuclarists and Islamistst,' 47-65.

105 Code of Personal Status of 1956, Book 1 Marriage, articles 1-11. The CPS is made up of the following books, each of them includes a number of articles reconstituting the legal status women and the family, for al-zawāj (marriage), al-talāq (divorce), al-nafaqah (alimony), al-hadānah (child custody), al-nasab (determination of parenthood), al-laqüt (abandoned children), al-mafqūd (missing person/s) and almīrāth (inheritance).

106 Code of Personal Status of 1956, Book 1 Marriage, articles 1-11.

107 Code of Personal Status of 1956, Book 1 Marriage, articles 1-11.

108 Code of Personal Status of 1956, Book 1 Marriage, articles 1-11.

109 Code of Personal Status of 1956, Book 1 Marriage, articles 1-11. 
in a marriage contract being more advantageous to one party, leaving the other party in a vulnerable position. ${ }^{110}$ Which in many instances is again the female, very seldom it is the male. One has to be careful, as many other factors could also lead to a vulnerable party, for example, if the age is 15 years old for the female she may not be aware of her options, she may be inexperienced in the art of negotiating, being too dependent on the advice of the family who may not necessarily have the girls interest or well-being of the vulnerable party. ${ }^{111} \mathrm{We}$ must also be aware not to underestimate the maturity of young people, although to some degree this very much debatable. New legislation was included to eliminate constraints relating to interfaith marriages by disallowing Muslim women from marrying non-Muslim men. ${ }^{12}$ Other constraints to marriage are the prohibition of marriage between blood relations, others sharing affinity by marriage, children breast-fed by the same woman or couples whose marriage was terminated by a final decree of divorce. ${ }^{113}$ The impediments of a temporary nature are the existence of third party rights in the marriage or the iddah (referred to as the reconciliation period). ${ }^{114}$ The issue of polygamy has always been a highly contentious issue within an Islamic framework. According to the CPS, polygamy is prohibited. Marrying more than one woman shall incur the punishment of one year imprisonment and a fine of 240,000 francs or either of these. ${ }^{115}$ Bourguiba spearheaded the barring of polygamy, arguing that the Qur'anic verse requiring the equal treatment of wives was an impossible ideal. ${ }^{116}$ Furthermore, Bourguiba motivated polygamy, like slavery, should be prohibited as the practice was revealed in a special context at the time of its revelation.

110 Jansen, 'Muslim Brides and the Ghost of the Shari'a: Have the Recent Law Reforms in Egypt, Tunisia and Morocco Improved Women's Position in Marriage and Divorce and Can Religious Moderates Bring Reform and Make It Stick?' 181212.

111 Jansen, 'Muslim Brides and the Ghost of the Shari'a: Have the Recent Law Reforms in Egypt, Tunisia and Morocco Improved Women's Position in Marriage and Divorce and Can Religious Moderates Bring Reform and Make It Stick?' 181212.

112 Khedher, 'Tracing the Development of the Tunisian 1956 Code of Personal Status,' $1-36$.

113 Code of Personal Status of 1956, Book 1, article 14, which states that: "The impediments to marriage are of two types, namely, perpetual and temporary".

114 Code of Personal Status of 1956, Book 1, article 14.

115 Code of Personal Status of 1956, Book 1, article 18.

116 Mashhour, 'Islamic Law and Gender Equality - Could there be a Common Ground?: A Study of Divorce and Polygamy in Sharia Law and Contemporary Legislation in Tunisia and Egypt,' Human Rights Quarterly, vol. 27/2 (2005): 562585 . 
Not surprisingly, the Tunisian traditionalists were unsatisfied with this particular interpretation and argued that the Qur'anic verse/s requiring equal treatment of wives had always been regarded as a moral suggestion. ${ }^{117}$ The traditionalist argument was that the verse/s clearly referred only to the financial treatment of wives and other similar equalities subject to human competence. Bourguiba's understanding was thus deemed to in direct conflict with the traditional interpretation of the practice of polygamy. ${ }^{118}$ Although some have argued that article 18 had not rendered polygamous marriages invalid, but merely instituted secular sanctions, ${ }^{119}$ the Minister of Justice, Al Snousi, at that time stood firm in the conviction that the equal treatment of wives was impossible. ${ }^{120}$ By barring polygamy, inferences can be drawn that Tunisia has indirectly or directly condemned the idea that women are to be deemed possessions and/or symbols enhancing the social, economic or political status of men. Also, by outlawing polygamy, Tunisia may well have ensured a degree of psychological comfort and stability for women who may otherwise live in fear that their husbands may conclude a further marriage. Of concern was article 23, which stipulates that the wife must fulfil her matrimonial duties "in conformity with usages and custom". ${ }^{121}$ Article 23 thus implies acceptance of pre-modern Islamic jurists' thinking that a wife must accede to the husband's sexual or other demands in the absence of a valid excuse. Mayer, a legal scholar, correctly points out that there is no stipulation that mutual affection should be the foundation for marital attachment or that cohabitation could be interpreted as the spouses' mutual obligation. ${ }^{122}$ Apart from the modification of Islamic law, the government had to reconcile legal disputes which arose amongst Muslim citizens. While the Mālikī and Hanafì judges (qadis) continued to exist side by side during the Ottoman Empire, these two competitive jurisdictions could

117 Bonderman, 'Modernization and Changing Perceptions of Islamic Law,' Harvard Law Review (1968): 1169-1185.

118 Bonderman, 'Modernization and Changing Perceptions of Islamic Law,' 11691185 .

119 Bonderman, 'Modernization and Changing Perceptions of Islamic Law,' 11691185 .

120 Bonderman, 'Modernization and Changing Perceptions of Islamic Law,' 11691185.

121 Code of Personal Status of 1956, Book 1, article 23.

122 Mayer, 'Reform of Personal Status in North Africa: A Problem of Islamic or Mediterranean Laws?' Middle East Journal (1995): 432- 440. 
no longer be justified once independence was achieved. ${ }^{123}$ To find a solution, Tunisia abolished the Shariah/religious courts. The result would be that the national courts would now adjudicate disputes relating to family law. The creation of the CPS seemed to serve another purpose besides family law. The CPS should be flexible of being applied by Western-trained judges, hence the abolishing of the Shariah/religious courts in favor of the national courts. ${ }^{124}$ This part of the article addresses the latest amendments to the CPS in the realization of women- friendly rights in Tunisia. The CPS has been revised several times since 1956.

The revised article 3, now states that marriage is formed only by free will of the parties. Furthermore, it now requires the bride to present at the place of the marriage contract and requires the woman to direct her opinion to the marriage expressly. ${ }^{125}$ The principle of the matrimonial guardian is abolished. The law no longer sanctions arranged or forced marriages of both parties. Forced and arranged marriages apply to both genders and has become a gender- neutral issue. ${ }^{126}$ The law currently strips away the father as well as the guardian's legal prerogative to hand over the male or female in marriage against their will. ${ }^{127}$ The marital age of both parties has been set at eighteen years of age ${ }^{128}$, which aligns itself with various international human rights regarding the age

123 This created a path for the introduction of the Code of Personal Status (majallat al-ahwal al-shakhsiyah) that could have the flexibility of being applied by Western-trained judges in the national courts. The Tunisian judicial system thus consisted of an elaborate melting pot influenced by the former Hanafì and Mālikī Shariah courts, a rabbinical tribunal for the Jews applying mosaic law, a small native community of Christians subject to the French Civil Code as applied by the Tunisian national courts, and finally, as per agreement with the French during negotiations, special "mixed" and "foreigners" courts responsible for the handling of disputes involving non-Tunisians.

124 Charrad, 'Policy Shifts: State, Islam, and Gender in Tunisia, 1930s-1990s,' 284319.

125 Tunisia's 1956 Code of Personal Status available at http://chnm.gmu.edu, accessed on 29 May 2019.

126 A comprehensive discussion relating to arrange and forced marriages is beyond the scope of this paper.

127 Tunisia's 1956 Code of Personal Status, available at http://chnm.gmu.edu, accessed on 29 May 2019.

128 'Convention to Consent to Marriage, Minimum Age for Marriage and Registration of Marriages,' available at https://www.ohchr.org, accessed on 20 December 2019. 
of marriage. ${ }^{129}$ The CPS indicates that the marriage could only be concluded before two notaries or an officer of the civil registry and registered with the civil authorities. ${ }^{130}$ A certificate delivered by the civil registry, or by the two notaries after they performed the marriage, has now become the only valid proof of marriage, thus trying to eliminate those contemplating to marry in secret. Although marriage in secret still happens as well as certain customary marriages especially in rural areas. ${ }^{131}$

Article 5 reads that each spouse who has not attained the age of eighteen years cannot marry. Below this age, the marriage cannot be contracted except by special permission from the judge who will grant permission only for serious reasons and in the best interest of the child. ${ }^{132}$ According to Chekir, the age limit prevents early marriages which permit sexual intercourse between partners are physically or mentally mature, as well as delaying motherhood thereby reducing the number of children in Tunisia, which about 50 percent of the population is born under the age of 20 years. ${ }^{133}$ Furthermore, it may be argued that premature childbearing before full physical maturity has the potential to impact the reproductive and sexual health of women. ${ }^{134}$ Early childbearing maybe also prove to be a stumbling block for those who wish further their education and wanting a profession, not underscore the emotional and psychological impact this may have on women. These issues could be

129 Code of Personal Status of 1956, Amended by Act No. 2007-32 of 14 May 2007. In 2007, the CPS was amended to set the minimum age of marriage at 18 for both boys and girls. Boys and girls below this age can only get married after the consent of both their guardian and their mother, and with special authorization from a judge. Such authorization can only be granted in extremely serious cases and in the best interest of the spouses. UNICEF, 'Tunisia Mena Gender Equality Profile Status of Girls and Women in the Middle East and North Africa,' available at http://www.unicef.org/gender/files/tunisia-Gender-Equality-Profile-2011.pdf, accessed on 12 May 2018.

130 Tunisia's 1956 Code of Personal Status, available at http://chnm.gmu.edu, accessed on 29 May 2019.

131 Voorhoeve, 'Judicial Discretion in Tunisian Personal Status Law,' in Family Law in Islam: Divorce, Marriage and Women in the Muslim World (London: Taurus, 2012), 1-35.

132 ACPF, 'In The Best Interest of the Child: Harmonising Law on Children in Eastern and Southern Africa,' available at http://www.africachildinfo.net, accessed on 29 May 2018.

133 Chekir, 'Women, the Law, and the Family in Tunisia,' Gender and Development, vol. 14/2 (1996): 43-46.

134 Chekir, 'Women, the Law, and the Family in Tunisia,' 43-46. 
attributed to early childbearing, although this in certain instances may also affect the male, who might not be ready to take on parental responsibilities and thus leaving it to the woman, in most instances.

Medical certificate of good health of the spouses was mandatory to prevent venereal or sexually transmitted contagious diseases, to protect the physical and emotional well-being of the child, wife and husband. ${ }^{135}$ The results of the tests are provided for in minutes for the parties. In the past these tests took up to three days. ${ }^{136}$ However, in a rural setting, these tests may take longer. ${ }^{137}$ There seems to be corruption and bribery taking place. ${ }^{138}$ These violations present itself despite the fact that this law has been inexistence the past fifty years and provides that a 'free' pre-marital medical test be performed by public clinics as well as public hospitals prior to the marriage ceremony. According to Arab Reporters for Investigative Journalism (ARIJ) report, Law No. 46/1964, states guidelines relating to the pre-marital testing, there are certain shortcomings, for example, it relies on the morality of the doctor. Doctors are meant to issue certificates after the couple performs several legally required tests. If this is not performed by the doctor the law does not impose any punitive measures. ${ }^{139}$ In addition, the regulatory aspect of Law No. 46/1996 has potential shortcomings. If the doctor complies with the necessary provisions of the law, his role is limited to only informing the parties of condition and issuing a warning of any consequences that may be passed to the child. ${ }^{140}$ Although, the doctor has the authority to withhold the certificate or postponing it for a later date,

135 Omri, 'Women and Marriage in Secular Islamic Country,' 147-149; Law No. 46/1964.

136 The tests that make up the pre-marital screening include the following, complete blood count and blood film, blood group, HB electrophoresis (for Thalassemia trait), hepatitis B surface antigen, rubella Ig (females only) - confirms the presence of adequate immunity against the rubella virus. Further optional tests that many couples chose to add as an extra precaution include, HIV, Syphilis, Chlamydia, seminal fluid analysis and fertility hormones.

137 'Arab Reporters for Investigative Journalism ARIJ,' available at http://en.arij.net, accessed on 20 May 2019.

138 This is what the reporters documented after a year's investigation in the field. According to official figures, 162,990 out of a total population of 10,866 million are suffering from disabilities. Eight out of ten couples that were accompanied violated the law requiring pre-marital tests; five of them through 'shaming' and three paying bribes.

139 'Arab Reporters for Investigative Journalism ARIJ,' available at http://en.arij.net, accessed on 20 May 2019.

140 'Arab Reporters for Investigative Journalism ARIJ.' 
this is circumvented by going to another doctor. ${ }^{141}$ In order to combat these shortcomings, the state introduced Law No. 17/1992, which states 'that any person knowingly infected with a communicable disease (venereal diseases) and goes out of his way to pass along this disease to another person shall be punished with a period ranging between one and three years' ${ }^{142}$ In addition, article 153, which was amended on 12 July 1993, granted a married woman who is a minor the right to manage her private affairs, due to her emancipation to adulthood through marriage. ${ }^{143}$

Article 2 on breach of promise of marriage was modified with Law No. 93-97 of 12 July 1993, and stated that 'each of the two fiancés shall have the right to restitution of gifts given to each other except in the case of breach of promise or a stipulation to the contrary. ${ }^{144}$ Article 12 relates to the dowry and states that it may consist/s of any lawful property having monetary value and it shall now belong to the wife. In contrast, the previous wording of article 12 relating to dowry provided that only the fiancés or the husband had the right to the repayment of any gifts given to the fiancée or wife.

Article 23 concentrates on mutuality, requiring both spouses to be kind to one another, to maintain good relation, and to avoid harming each other. ${ }^{145}$ They have to work together to manager the home, raising the children, and provide for the needs of the children. According to Mayer, the language of the CPS closely resembles the modern French Civil Code, article 213, which stipulates that the spouses together ensure the moral and material direction of the family, provide for the education and preparation for the future. ${ }^{146}$ The old

141 'Arab Reporters for Investigative Journalism ARIJ.'

142 Law No. 71/1992, dealing with communicable diseases. In Tunisia and perhaps in other Muslim countries the marriage between cousins in not uncommon, therefore, due to the marriage of cousins the pre-marital certificate could proof to be useful in order to prevent the passing on hereditary diseases to child born out of such marriages. According to Dr Lamia Bin Jum'a, Director of the Genetic and Hereditary Diseases Department at the Manji Salim government hospital, and an expert in hereditary sciences, says the cost of treatment of patients suffering from hereditary diseases increases with age.

143 Code of Personal Status of 1956, article 153, amended in 1993.

144 Code of Personal Status of 1956, article 2, amended with Law No. 93-97 in 1993.

145 Mayer, 'Reform of Personal Status in North Africa: A Problem of Islamic or Mediterranean Laws?' 432-440.

146 Mayer, 'Reform of Personal Status in North Africa: A Problem of Islamic or Mediterranean Laws?' 432-440. 
language of the CPS requiring the wife to adhere to the husband's prerogatives and to show obedience has now been abolished. ${ }^{147}$

Article 23 still refers to the husband as head of the family, raising serious questions of interpretation. On the question of interpretation, Mayer, puts forward the following, perhaps the status of the husband as head of the household could be interpreted to mean that he retains decision-making prerogatives and that the wife should defer to his wishes. ${ }^{148}$ Alternatively, it may reflect the primary responsibility that he has to provide to his family according to his means. ${ }^{149}$ Furthermore, article 23 directs the wife to contribute, too, if she has money. ${ }^{150}$ The provision stipulating that the wife must fulfil her conjugal duty in conformity to custom and usages was revised in 1993. The revised provision required that both parties to fulfil their duties conforming to custom and usages of pre-independence family structure. ${ }^{151}$ Despite the modes of interpretation, the revisions that have taken place the CPS is undoubtedly moving the progressive realization of equal rights coupled with equal responsibilities of the spouses. ${ }^{152}$ It means that the wife plays an active role within the family as a generator of economic resources. According to Grami, commenting on the substance of

147 It is unlikely that the husband's right to forbid his wife to work outside the home will survive the elimination of the wife's duty of obedience, but, in the absence of a specific provision guaranteeing the wife's right of work, uncertainty remains.

148 Mayer, 'Reform of Personal Status in North Africa: A Problem of Islamic or Mediterranean Laws?' 432-440.

149 Mayer, 'Reform of Personal Status in North Africa: A Problem of Islamic or Mediterranean Laws?' 432-440.

150 The Tunisian custom has retained patriarchal elements, which on the one hand, give the husband more rights and wife more duties, could mean a continuance of the privileges traditionally enjoyed by the husband under the rubric of custom. On the hand, that particular custom may be evolving away from the archaic family law model in a new direction of making marriage more akin to a partnership between equals. Code of Personal Status of 1956, article 123, under Law No. 93-74 of 12 July 1993.

151 Tunisia's 1956 Code of Personal Status, available at http://chnm.gmu.edu, accessed on 29 May 2019.

152 Formerly, because the family guardian was the father or his representative, the mother had no right to intervene in any decision relating the marriage of the minor child. The amendment of this article has brought an end to his inequality. According to the revised article 6 of the CPS, the mother has the identical right as the father or guardian to authorise the marriage of the minor child. The revised article 6 states the marriage of a minor shall be subject to the consent of his or her guardian, as well as that of the mother. This has created joint parental authority regarding the well-being of the minor child when it comes to marriage. 
article 23, states that Tunisian women do have not only have equal rights with their male counterparts but also equal responsibilities in monetary terms. ${ }^{153}$ It is too early to discuss the application and consequences of how article 23 , will affect the marriage and the family in the future.

Before 1956, unilateral repudiation, which is a widespread Muslim tradition, allowed the husband to divorce his wife with impunity and freely. ${ }^{154}$ The CPS has changed the regulations progressively relating to divorce. The improvement has abolished repudiation. ${ }^{155}$ The term 'repudiation' appears nowhere in the text of the CPS. A divorce can only take place in court. ${ }^{156}$ There are three possibilities of divorce -; mutual divorce agreement of both spouses, or at the request of one spouse because of harm to which that spouse has been subjected, or at the request of the husband. ${ }^{157}$

When a divorce is granted, the woman can demand compensation for any wrongs to which she has been subjected. She has a right to an allowance, payable monthly in arrears, which depends on the standard of living to which she was accustomed during the marriage. It may also be payable as a single capital sum. Furthermore, women whom custody of the children have the right to child support and there is also ${ }^{158}$ an alimony fund established in 1993 by the state, which ensures payments to divorced women and their children in case of the husband neglects his duties. Article 19 of the CPS, states that a

153 Grami, 'Gender Equality in Tunisia,' British Journal of Middle Eastern Studies (2000): 349-361.

154 Chekir, 'Women, the Law, and the Family in Tunisia,' 43-46.

155 Code of Personal Status of 1956, Book II.

156 Divorce options for men and women, 1) mutually agreed, 2) divorce by the wife or her husband establishing injury, 3) divorce upon the request of either spouse.

157 UNICEF, 'Tunisia Mena Gender Equality Profile Status of Girls and Women in the Middle East and North Africa.'

158 UNICEF, 'Tunisia Mena Gender Equality Profile Status of Girls and Women in the Middle East and North Africa.' 
man is forbidden to marry his 'triply-divorced wife', ${ }^{159}$ and article 14 describes 'triple divorce' as a permanent impediment to marriage. ${ }^{160}$ There has been considerable controversy over the interpretation of these provisions, and it is not certain whether a triply-divorced wife cannot marry her former husband even if the resulting bar has been removed following the procedure described by law. ${ }^{161}$ On September 142017 , the Tunisian government put an end to the ban (44 year ban imposed in 1973) on inter-religious marriages between Tunisian Muslim females and non-Muslim males, issued by non-other the Tunisian president Beji Caid Essebsi. ${ }^{162}$ During the president's speech on National Women's Day, he proposed amendments relating to the provisions governing the rule of inheritance and marital contracts. ${ }^{163}$ The president presented the revoking of the provision relating to the inheritance that grants men the right to inherit twice as much as women and the introduction of new provisions that allow women to inherit on an equal basis with men. Also, the president put forward the removal of a bar that prevents inter-religious marriages between Muslim women and non-Muslim men. It has always been legal for men to marry outside their religion. ${ }^{164}$

159 Under the rubric of Islam, husband can divorce his wife thrice. With a view to establish a check on the pre-Islamic practice of innumerable divorces followed by revocation or remarriage leaving the wives in a distressing condition of uncertainty, Islam introduced the concept of baynunat al-kubra, a big interval. This meant that when a husband divorces his wife for the third time, a baynunat al-kubra is established between the divorced couple and the man cannot marry his divorced wife. Within Islam there is a way to overcome this obstacle. The method that is used should the husband desire to marry his triply divorced-divorced wife, he could contract her into marriage with one of his relatives with the understanding that the intervening marriage will never be consummated and that a divorce would follow after which the first husband would be able to marry his divorced wife again. The dominate Sunni schools of thought have problems with recognising this evasive measure. Muslim countries have addressed this issue by providing that the intervening marriage should not be contracted with intention of a planned dissolution to be instituted.

160 Code of Personal Status of 1956, articles 14 and 19.

161 Anderson, 'Reforms in Family Law in Morocco,' 146-159.

162 Al Jazeera, 'Tunisia Lifts Ban on Muslim Women Marrying Non-Muslims,' available at http://aljazeraa.com, accessed on 14 May 2019.

163 Nadhif, 'Tunisian President Calls for Gender Equality in Inheritance Law,' $A$ Monitor, 21 August 2017, available at http://almonitor.com, accessed on 14 November 2019.

164 Mosaique, 'Essebi Calls for the Modification of a Piece of Legislation Banning Tunisian Women from Marrying Non-Muslims,' 13 August 2017, available at http://al-monitor.com, accessed on 14 November 2019. 
The announcement by the president has received widespread condemnation among religious groups, which put forward that these latest provisions are in direct opposition to Islamic law, as it is Islamic law that prevails over family matters. These religious groups contend that these latest provisions allowing inter-religious marriages and the granting of equal portions of inheritance to female's conflicts with the Quran and main principles of Islamic Law. ${ }^{165}$ However, those supporting the president argue that this approach towards inter-religious marriages and women inheritance aligns itself with article 21 of the 2014 Tunisian Constitution. ${ }^{166}$ Article 21 provides that "all citizens, male or female, have equal rights and duties, and are equal before the law without any discrimination". Furthermore, those supporting the president argue that the proposed amendments are also in line with article 46 of the Constitution, which states "the state commits to protect women's accrued rights and works to strengthen and develop those rights" and "that state guarantees the equality of opportunities between women and men to have access to all levels of responsibilities in all domains". ${ }^{167}$

Despite spearheading modernizing legislation relating to women's rights, remnants of old patriarchal structures exist and the cultural tendency to males more superior to females is a reality in Tunisia. ${ }^{168}$ Furthermore, there exists a tension between the notion of gender equality and religious identity that encourages traditional division along with gender roles, particularly in the realm of the family. The CPS now gives Tunisian women the right to negotiate their marital contract, however, in practice social pressure influences this

165 Sayed, 'Tunisian Opposition Call for Ouster of President Essebsi,' Egypt Today, 16 August 2017, available at www.egypttoday.com, accessed on 25 November 2019. In Egypt, Al Azhar, the world's most foremost seat of religious learning for Sunni Muslims, swiftly rejected the Tunisian proposals by its president. Abbas Shoman, Al Azhar's, second most senior cleric stated, that calls for equality of men and women in inheritance do an injustice to women, don't do women any good and clash with Shariah. As for the reforms in marriage law, Mr Shoman argued that that while Muslim men were likely to respect the beliefs and freedom to worship of their non-Muslim spouses, non-Muslim men were unlikely to do the same for their Muslim wives. The National, 'After Marriage Laws, Tunisia Now Tackles Women's Inheritance Rights,' available at http://www.thenational. ae, accessed on 21 November 2019.

166 The Tunisian Constitution of 2014, available at http://constitutionnet.org, accessed on 14 November 2019.

167 Nadhif, 'Tunisian President Calls for Gender Equality in Inheritance Law.'

168 Ben Salem, 'Tunisia,' Women's Rights in the Middle East and North Africa: Progress amid Resistance, ed. Sanja Kelly \& Julie Breslin (Lanham and New York: Rowman \& Littlefield Publishers and Freedom House, 2010), 487-516. 
more than the law. ${ }^{169}$ Generally, the recognition and understanding of the continuously changing nature of Islamic teachings with the evolving nature of the Shariah can accommodate activists with the information aspects to produce counter-narratives to patriarchal and discriminatory discourses on women's rights, roles and duties. ${ }^{170}$

\section{THE STATE AND THE CODIFICATION OF MUSLIM FAMILY LAW}

When referring to the reforms that have taken place in Tunisia and Morocco, they can be classified as either traditionalist/conservative or reformist/liberal. These classifications are, however, dependent on a series of inter-related influences. These inter-related influences could include the political will of the state and its representatives, the role of early reformers, the presence or emergence of a vibrant women's movement that strives for reform which, addresses new lived realities of women, children and men, as well as a societal environment which is acceptable. ${ }^{171}$ When assessing the reforms, it is important to realise that the codification of family laws was not an association of the most prevalent opinions of reformers on every matter, but rather, the codification was an expression of an eclectic choice from a plethora of opinions which was adopted for their appropriateness to meet the needs of modern life. ${ }^{172}$ Sonbal puts forward the argument that family law practiced in the Muslim states as being pure Shariah even though it is historically that the present laws are a product of a long historical process involving Shariah laws. ${ }^{173}$ Furthermore, cumulative interpretations of Islamic law over long periods, including western legal practice, local traditions as well as gender philosophy have influenced Morocco's and Tunisia's family law. ${ }^{174}$ Hallaq, rightly argues, the importance

169 Ben Salem, 'Tunisia,' 487-516.

170 Mashhour, 'Islamic Law and Gender Equality - Could there be a Common Ground?: A Study of Divorce and Polygamy in Sharia Law and Contemporary Legislation in Tunisia and Egypt,' 562-585.

171 Sharafeldin, 'Gender and Equality in Muslim Family Law,' (Paper presented, United Nations Expert Group Meeting, Department of Economic and Social Affairs (UNDESA) Division of Social Policy and Development, "Family Policy Development: Achievements and Challenges” New York, 14-15 May 2015), 1-17.

172 Anderson, Law Reform in the Muslim World (London: University of London Athlone Press, 1976), 1-339.

173 Sonbol, 'A Response to Muslim Countries' Reservation Against Full Implementation of CEDAW,' Journal of Women of the Middle East and the Islamic World, vol. 8/3 (2010): 348-367.

174 Sonbol, 'A Response to Muslim Countries' Reservation Against Full Implementation of CEDAW,' 348-367. 
of dialogue with existing states structures if any meaningful reform is to be undertaken relating to the laws governing Muslims. ${ }^{175}$ Tucker underscores this by demonstrating that in their efforts to modernize and codify its family law, early twentieth century reformers had the backing of their respective states, some parts of the community and various organizations. ${ }^{176}$ Furthermore, the undertaking was not an intellectual exercise in reviewing the law, but also the perspective of the state on specific projects and agendas. ${ }^{177}$ In every instance of legal reform encompassed the authority of state power over religious courts, personnel as well as the fundamental questions of identity implicit in marriage/s. ${ }^{178}$ From the above, inferences may ascertain how the state and its representatives to a certain degree intentionally chose which interpretations of the Islamic law to translate, adapt and codify. Shaham, argues, this was often based on a restrictive perspective of political gain and the expediency for the political elite and those in charge of power rather than to affect meaningful social change. ${ }^{179}$

Morocco and Tunisia are good examples which demonstrate that they are not really-up to the state to promulgate gender-sensitive and egalitarian Muslim family laws. There must be consultations with the various actors. Both countries have presented preference interpretations of the Islamic law with regards to the rights and duties of parties relating to the institution of marriage and perhaps divorce also. According to Sharafeldin, such alternative jurisprudence is consistent with many rights as contained in CEDAW, ${ }^{180}$ to which most Arab countries opted to insert reservations. Tunisia, has lifted all its reservations to CEDAW, ${ }^{181}$ whereas, Morocco in 2008, the monarchy announced the

175 Hallaq, 'Can the Shari'a Be Restored?' in Islamic Law and the Challenges of Modernity Haddad, ed. Yvonne, Stowasser \& Babara (New York: Altamira Press, 2004), 21-53.

176 Tucker, Women, Family and Gender in Islamic Law (Cambridge: Cambridge University Press, 2008), 1-255.

177 Tucker, Women, Family and Gender in Islamic Law, 1-255.

178 Tucker, Women, Family and Gender in Islamic Law, 1-255.

179 Shaham, Family and the Courts in Modern Egypt: A Study Based on Decisions by the Shari'a Courts, 1900-1955 (Leiden: Brill, 1997), 1-289.

180 Convention on the Elimination of All Forms of Discrimination Against Women. GA Re34/180, UN GOAR 34 ${ }^{\text {th }}$ Session, Supp No 46, UN Doc A/34/36 (1980), adopted 18 December 1979.

181 Tunisia signed CEDAW in 1980 and ratified it in 1985, while issuing a general declaration statement positing that Tunisia "shall not take any organizational or legislative decision in conformity with the requirements of this Convention where such decision would conflict with the provisions of Chapter 1 of the Tunisian Constitution". Reservations were made to articles 9(2), 15(4), 16 and 29. 
withdrawal of all its reservations relating to CEDAW. ${ }^{182}$ In Morocco, it was the political establishment, the monarchy and the various actor's that contributed while in Tunisia it was the presidency that was committed to achieving gender friendly developments for women and to a lesser extent the expansion and commitment of women's movements. We should also not forget the role of the early reformers influences that created the atmosphere in both countries. In Tunisia, polygamy was abolished based on several Islamic methodological instruments, such as Qura'nic referencing, contextual analysis and analogy. ${ }^{183}$ The 2004 Moroccan reforms, albeit within an Islamic context relating to polygamy has made it procedurally extreme burdensome for a man to take more than one wife. In practical terms by attaching stringent conditions to polygamy. ${ }^{184}$ Polygamy in Morocco is retained whereas in Tunisia it has been abolished since 1956. This does mean that polygamy is not practised, there may be instances that it is still practiced in secret in both countries.

When it comes to divorce, Tunisia, gave men and women equal rights to institute proceedings against each other. Judicial intervention at a national level is now compulsory. Should the parties wish to proceed with divorce proceedings the unfettered reservation of the husband to utter the words "I divorce you" or "I talāq you" thus no more applicable. This reform was based on a new interpretation of existing jurisprudence as early as 1956. The 2004 reforms in Morocco are based on a similar procedure for divorce referred to as 'judicial divorce for discord based on the request of either spouse'. ${ }^{185}$ Tunisia and Morocco have perhaps undertaken one of the most challenging reforms in marriage by changing the status of the "wife's obligation of obedience to her husband". Both countries previously went by "the wife's obedience" in return for the maintenance equation. The reforms of 1993 introduced the concept of 'mutual duty' in Tunisia, which meant that both husband and wife are - equal in the decision within the family. The position now in both countries, is that no party in the marriage have to obey the needs and wants of the other. ${ }^{186}$

\footnotetext{
182 Sharafeldin, 'Gender and Equality in Muslim Family Law,' 1-17.

183 Sharafeldin, 'Gender and Equality in Muslim Family Law,' 1-17.

184 Naciri, 'The Moroccan Women's Movement: Dynamics of Reforming Personal Status Code,' (unpublished paper commissioned by the Deutsche Gersellschaft fur Technische Zusammenarbeit (GTZ) Office in Cairo, Egypt, 2007), 1-35.

185 Sharafeldin, 'Gender and Equality in Muslim Family Law,' 1-17.

186 Brandt \& Kaplan, 'The Tension between Women's Rights and Religious Rights: Reservations to CEDAW by Egypt, Bangladesh and Tunisia,' Journal of Law and Religion (1995-1996): 399-468.
} 
In many Muslim countries, CEDAW was made to pose an obstacle towards the realization and emancipation of women-friendly rights in the context of the family. From the above argument, it becomes ostensibly clear that the state in consultation with other actors, could entertain various interpretations of Islamic law when it came to the family, and that it does not have to an obstacle to the realization of the some of the rights outlined in CEDAW. In Morocco and Tunisia, the context of which the reforms have taken place enabled the use of its existing family laws to realize those same rights as outline in CEDAW. Therefore, one could argue that the change in the political and social landscape played a significant role in shaping the interpretation of Islamic law to respond to the needs of contemporary Muslim societies as well as aligning itself with various international human rights instruments.

The Moroccan constitution was first promulgated in 1972 and undergone several revisions with its latest in 2011. The preamble is an integral part of the Moroccan constitution and refers to the adherence to international human rights as arising from the various charters of international conventions. ${ }^{187}$ Article 3 declares Islam to be the State religion and guarantees freedom of worship for all. ${ }^{188}$ Under the 1996 constitution the issue of Islam as the State religion was found in article 6. Title II: Fundamental Freedoms and Rights states that men and women will enjoy equal rights. ${ }^{189}$ Article 22 refers to the degrading treatment or the infringement of a person's dignity. ${ }^{190}$ Moroccan's are guaranteed freedom of thought, of opinion and of expression under all their forms. ${ }^{191}$

Tunisia promulgated its first post-independent constitution in 1959. Like Morocco's preamble, Tunisia's preamble is an integral part of the constitution. The Tunisian preamble resembles South Africa's preamble makes references to the uprising which place during December 2010 through January 2011,

187 Morocco Constitution of 2011 available at http://www.constitutionprogectorg/ Constitution/Morocco2011PDF, accessed on the 5 October 2019.

188 Morocco's Constitution of 2011, article 3.

189 Morocco's Constitution of 2011, article 19 which reads; "The man and the woman enjoy, equality, the rights and freedoms of civil, political, economic, social, cultural and environmental character, encountered in this Title and in other provisions of the Constitution, as well as in the international conventions and pacts duly ratified by Morocco and this, with respect for the provisions of the Constitution, of the constants of the Kingdom and of its law'.

190 Morocco's Constitution of 2011, article 22.

191 Morocco's Constitution of 2011, article 25. 
is striving for dignity and freedom. ${ }^{192}$ The preamble also acknowledges the sacrifices of those who fought and died to break the shackles of tyranny and the fight for freedom. ${ }^{193}$ Jansen, notes that the Tunisian preamble makes both a United Nations Charter format reference to the common heritage of its peoples attached to human dignity, justice and liberty. ${ }^{194}$ Adherence is made to Islam, as article 1 states that Islam is regarded as the religion of the state. ${ }^{195}$ Article 1 may not be amended this has been a thorny issue in the negotiating process. Article 6 states that the state is the guardian of religion. The 2002 constitution states that the president must be a Muslim. Inferences may be drawn from the 2002 constitution that the president had to be male. The 2014 Tunisian constitution now states that every male or female voter who is in possession of Tunisian nationality since birth and whose religion is Islam shall have the right to stand for election to the position of president of the Republic. ${ }^{196}$ Article 19, of the 2014 Tunisian constitution, expressly stipulates that international agreements 'shall be superior to laws and inferior to the constitution'. This confirms the elevated status of international treaty law in and Tunisia's ensuing obligations under the new constitutional dispensation. Jansen puts forward that these rights can only be enjoyed within the boundaries set by law and in so far as their enjoyment is not restricted by a law enacted for the protection of certain purposes, this ties with article $21 .{ }^{197}$ It must be said that the Arab uprising in the Mena region has had more of an impact on the drafting of the Tunisian constitution as compared to the Moroccan constitution. It is noteworthy, to mention a few distinct features between the two constitutions. Of interest, is the fact that many Moroccan's did not target the King or demand a change of the regime, instead they called for an unaffected constitutional monarchy, the disbanding of parliament, the dismissal of Prime Minister Abbas El-Fassi and the many relatives occupying senior positions in government as

192 The Republic of South Africa Constitution of 1996, the preamble.

193 Preamble to the Tunisian Constitution of 2014.

194 Jansen, 'Muslim Brides and the Ghost of the Shari'a: Have the Recent Law Reforms in Egypt, Tunisia and Morocco Improved Women's Position in Marriage and Divorce and Can Religious Moderates Bring Reform and Make It Stick?' 181212.

195 The Tunisian Constitution of 2014, Title One: General Principles, article 1.

196 The Tunisian Constitution of 2014, Title Four: The Executive Authority, article 74.

197 Jansen, 'Muslim Brides and the Ghost of the Shari'a: Have the Recent Law Reforms in Egypt, Tunisia and Morocco Improved Women's Position in Marriage and Divorce and Can Religious Moderates Bring Reform and Make It Stick?' 181212. The Tunisian Constitution of 2014, Title Two: Rights and Freedoms, article 21. 
well as the entire cabinet. ${ }^{198}$ The protest that Tunisia experienced could in part be attributed to its authoritarian government. Notable features of such governments is the lack of free and fair elections as well as the imposition of various restrictions imposed on the formation and well-being of political parties. ${ }^{199}$ The 2014 constitutional provisions protects civil liberties, separates legislative, executive and judicial powers, guaranteeing women parity in political institutions, and declares that Islam is the country's official religion while at the same time protecting religious freedom for all. An important facet is the homogeneity of Tunisian society - which although has some divisions, did not suffer fragmentation along religious, political, cultural or ethnic lines, as is the case in other Muslim states. ${ }^{200}$

\section{CONCLUSION}

Although both countries since independence leaned towards modernity and struggled at different speeds to make a complete break from the past and embrace modernity in totality, there are changes in the prevailing order of gender roles. Evidence of this is to be found in marriage and divorce patterns which no longer reflect the larger family but rather the wants and expectations of the person. However, one must not forget that although women rights are a priority on the state's agenda, in practice social pressure still plays a very decisive role in both countries, when it comes to the family, especially to marriage and divorce. This change is also reflected in communities, more so in the urban environment than the rural setting. In both countries, the rural setting is an area of great concern. In the rural setting remnants of the old patriarchal structures (which is becoming more gender neutral, which also a cause for concern) seems to be playing a greater role in those outlying districts. Morocco and Tunisia have demonstrated unequivocally that confident assertion unequivocally by Muslim countries relating to the difficulty of reforming their respective family laws, because they are based on divinity and being immutable contradicts with reality. ${ }^{201}$ Furthermore, not only are these laws individual from one another

198 Denoeux G., 'Countries at a Crossroads 2011: Morocco,' available at http:// freefomhouse.org., accessed on 6 June 2019.

199 Dewey, Kaden, Marks, Matsushima \& Zhu, 'The Impact of Social Media on Social Unrest in the Arab Spring,' available at http://www.publicpolicystanford, accessed on 5 November 2019.

200 Tunisia's Constitution of 2014 - Constitute Project https://www.constituteproject. org, accessed on 10 December 2019.

201 Mayer, 'Rhetorical Strategies and Official Policies on Women's Rights: The Merits and Drawbacks of the New World Hypocrisy,' in Faith and Freedom, ed. Akkhami, Mahnaz (London: Tauris, 1995). 
despite them being embedded on the same source, being Islamic Law. In addition, being historically, the same Islamic law has constantly changed and been adapted when the state wished to do so. Welchman, underscores this point by providing a list of Muslim countries as well as their family laws and reforms through time. ${ }^{202}$ From an international perspective, the with-drawl of certain reservations which were in place for some time is definitely a signal, of both countries willingness to adopt international provisions at a national level. This bolds well for the future for the furthering of basic and fundamental rights of women and children. Both countries, seems to be fighting a new battle or perhaps an old battle, which has brought to the front religious identity versus the identity of the person. This is to be expected, whenever, there is a transition from the old to the new, heated debates will erupt. This may not necessarily be a bad thing, it could be a good thing, in which it creates an atmosphere for dialogue. Morocco and Tunisia must be complicated and encouraged to press on with the current reforms in the area of the family, because inequality is still very much alive. In addition, there are new concerns coming to the front, those forming political parties and calling for a return to the pre-codification of both countries' family law reform. The 2014 constitutional provisions protects civil liberties, separates legislative, executive and judicial powers, guaranteeing women parity in political institutions, and declares that Islam is the country's official religion while at the same time protecting religious freedom for all. An important facet is the homogeneity of Tunisian society - which although has some divisions, did not suffer fragmentation along religious, political, cultural or ethnic lines, as is the case in other Muslim states.

\section{REFERENCES}

'Arab Reporters for Investigative Journalism ARIJ,' available at http://en.arij. net, accessed on 20 May 2019.

'Convention to Consent to Marriage, Minimum Age for Marriage and Registration of Marriages,' available at https:/www.ohchr.org, accessed on 20 December 2019.

ACPF, 'In The Best Interest of the Child: Harmonising Law on Children in Eastern and Southern Africa,' available at http://www.africachildinfo. net, accessed on 29 May 2018.

Al Jazeera, 'Tunisia Lifts Ban on Muslim Women Marrying Non-Muslims,' available at http://aljazeraa.com, accessed on 14 May 2019.

202 Welchman, Women and Muslim Family Laws in Arab States: A Comparative Overview of Textual Development and Advocacy (Amsterdam: Amsterdam University Press, 2007), 1-256. For example, countries such Algeria, Egypt, Jordan, Libya, Qatar, Palestine, Syria, United Arab Emirates and Yemen. 
Anderson, 'Reforms in Family Law in Morocco,' Journal of African Law (1958): 146-159.

Anderson, Law Reform in the Muslim World (London: University of London Athlone Press, 1976).

Angrist, 'The Expression of Political Dissent in the Middle East: Turkish Democratization and Authoritarian Continuity in Tunisia,' Comparative Studies in Society and History (1999): 730-748.

Ben Salem, 'Tunisia,' Women's Rights in the Middle East and North Africa: Progress amid Resistance, ed. Sanja Kelly \& Julie Breslin (Lanham and New York: Rowman \& Littlefield Publishers and Freedom House, 2010), 487-516.

Bonderman, 'Modernization and Changing Perceptions of Islamic Law,' Harvard Law Review (1968): 1169-1185.

Booley, 'Progressive Realisation of Muslim Family Law: The Case of Tunisia,' PELJ (2019): 1-22.

Bordat \& Kouzi, 'The Challenge of Implementing Morocco's New Personal Status Law,' 2 Arab Reform Bulletin 8 (2004), available at www.ceip. org/arabreform, accessed on 20 May 2019.

Brandt \& Kaplan, 'The Tension between Women's Rights and Religious Rights: Reservations to CEDAW by Egypt, Bangladesh and Tunisia,' Journal of Law and Religion (1995-1996): 399-468.

Büchler \& Schlatter, 'Marriage Age in Islam and Contemporary Muslim Family Laws: A Comparative Survey,' Electronic Journal of Islamic and Middle Eastern Law, vol. 1 (2013): 37-74.

Buskens, 'Recent Debates on Family Law Reform in Morocco: Islamic Law as Politics in an Emerging Public Sphere,' Islamic Law and Society (2003): 70-75.

Camelleri, 'Modernity and the Tunisian Family in Tunisia,' Journal of Marriage and the Family (1967): 590-595.

Campbell, 'Morocco in Transition: Overcoming the Democratic and Human Rights Legacy of King Hassan II,' Journal of Democracy, vol. 23/1 (2012): 38-42.

Catroux, 'France, Tunisia and Morocco,' International Journal: Canada's Journal of Global Policy Analysis (1954): 282-294.

Charrad, 'Family Law Reforms in the Arab World: Tunisia and Morocco,' (Report for the United Nations, Department of Economic and Social Affairs (UNDESA) Division for Social Policy and Development, Expert Group Meeting, New York, 15-17 May 2012), 1-14. 
Charrad, 'Policy Shifts: State, Islam, and Gender in Tunisia, 1930s-1990s,' Social Politics, vol. 4/2 (1997): 284-319.

Charrad, 'State and Gender in the Maghrib,' Middle East Report (1990): 1920.

Charrad, 'Tunisia at the Forefront of the Arab World: Two Waves of Gender Legislation,' Washington \& Lee Law Review (2007): 1513-1527.

Chekir, 'Women, the Law, and the Family in Tunisia,' Gender and Development, vol. 14/2 (1996): 43-46.

Denoeux G., 'Countries at a Crossroads 2011: Morocco,' available at http:// freefomhouse.org., accessed on 6 June 2019.

Dewey, Kaden, Marks, Matsushima \& Zhu, 'The Impact of Social Media on Social Unrest in the Arab Spring, available at http:/www. publicpolicystanford, accessed on 5 November 2019.

Garcés, 'Islam, Till Death Do You Part? Rethinking Apostasy Laws Under Islamic Law and International Legal Obligations,' Northwestern Journal of International Law (2010): 248.

Grami, 'Gender Equality in Tunisia,'British Journal of Middle Eastern Studies (2000): 349-361.

Hallaq, 'Can the Shari'a Be Restored?' in Islamic Law and the Challenges of Modernity Haddad, ed. Yvonne, Stowasser \& Babara (New York: Altamira Press, 2004), 21-53.

Howland, 'The Challenge of Religious Fundamentalism to the Liberty and Equality Rights of Women: An Analysis under the United Nations Charter,' Columbia Journal of Transnational Law, vol. 35 (1997): 271377.

Htun \& Weldon, 'State Power, Religion And Women's Rights: A Comparative Analysis of Family Law,' International Journal of Global Legal Studies (2011): 145-165.

Jansen, 'Muslim Brides and the Ghost of the Shari'a: Have the Recent Law Reforms in Egypt, Tunisia and Morocco Improved Women's Position in Marriage and Divorce and Can Religious Moderates Bring Reform and Make It Stick?' Northwestern Journal of International Human Rights, vol. 5/2 (2007): 181-212.

Kamali, Principles of Islamic Jurisprudence: Introdcution (Malaysia: International Islamic University Press, 1991).

Khedher, 'Tracing the Development of the Tunisian 1956 Code of Personal Status,' Journal of International Women's Studies, vol. 18/4 (2017): $1-36$. 
King Mohamed VI, 'Speech at the Opening of the Parliament Fall Session,' 10 October 2003 available at http://www.mincom.gov/ma, accessed on 19 May 2019.

Maddy-Weitzman, 'Women, Islam and the Moroccan State: The Struggle over the Personal Status Law,' Middle Eastern Journal, vol. 59 (2005): 396397.

Mashhour, 'Islamic Law and Gender Equality - Could there be a Common Ground?: A Study of Divorce and Polygamy in Sharia Law and Contemporary Legislation in Tunisia and Egypt,' Human Rights Quarterly, vol. 27/2 (2005): 562-585.

Mayer, 'Reform of Personal Status in North Africa: A Problem of Islamic or Mediterranean Laws?' Middle East Journal (1995): 432- 440.

Mayer, 'Rhetorical Strategies and Official Policies on Women's Rights: The Merits and Drawbacks of the New World Hypocrisy,' in Faith and Freedom, ed. Akkhami, Mahnaz (London: Tauris, 1995).

McCarthy, 'Re-thinking Securalism in post-independence Tunisia,' The Journal of North African Studies, vol. 19/5 (2014): 733-750.

Moosa, 'A Comparative Study of the South African and Islamic Law of Succession and Matrimonial Property with Special Attention to the Implications for Muslim Women,' (Master Dissertation, Faculty of Law, University of the Western Cape, Bellville, 1991).

Moosa, Unveiling the Mind: A Herstory of the Historical Evolution of the Legal Position of Women in Islam (Cape Town: Mills Litho, 2004).

Mosaiquefm, 'Essebi Calls for the Modification of a Piece of Legislation Banning Tunisian Women from Marrying Non-Muslims,' 13 August 2017.

Naciri, 'The Moroccan Women's Movement: Dynamics of Reforming Personal Status Code,' (unpublished paper commissioned by the Deutsche Gersellschaft fur Technische Zusammenarbeit (GTZ) Office in Cairo, Egypt, 2007), 1-35.

Nadhif, 'Tunisian President Calls for Gender Equality in Inheritance Law,' Al-Monitor, 21 August 2017, available at http://almonitor.com, accessed on 14 November 2019.

Omri, 'Women and Marriage in Secular Islamic Country,' Journal of Policy Studies (2005): 147-149.

Prettitore, 'Family Law Reform, Gender Equality, and Underage Marriage: A View from Morocco and Jordan,' The Review of Faith \& International Affairs, vol. 13/3 (2015): 32-33. 
Sayed, 'Tunisian Opposition Call for Ouster of President Essebsi,' Egypt Today, 16 August 2017, available at www.egypttoday.com, accessed on 25 November 2019.

Sfeir, 'The Tunisian Code of Personal Status (Majallat Al-Ahwal-Shakhsiyah),' Middle East Journal, vol. 11/3 (1957): 309-318.

Shaham, Family and the Courts in Modern Egypt: A Study Based on Decisions by the Shari'a Courts, 1900-1955 (Leiden: Brill, 1997).

Sharafeldin, 'Gender and Equality in Muslim Family Law,' (Paper presented, United Nations Expert Group Meeting, Department of Economic and Social Affairs (UNDESA) Division of Social Policy and Development, "Family Policy Development: Achievements and Challenges" New York, 14-15 May 2015), 1-17.

Sonbol, 'A Response to Muslim Countries' Reservation Against Full Implementation of CEDAW,' Journal of Women of the Middle East and the Islamic World, vol. 8/3 (2010): 348-367.

Stilt \& Gandhavadi, 'Strategies of Muslim Family Law Reform,' (Faculty Working Papers, Northwestern University School of Law Scholarly Commons, 2011).

Tagari, 'Personal Family Law Systems: A Comparative and International Human Rights Analysis,' International Journal of Law in Context (2012): 231-252.

The National, 'After Marriage Laws, Tunisia Now Tackles Women's Inheritance Rights,' available at http://www.thenational.ae, accessed on 21 November 2019.

Tucker, Women, Family and Gender in Islamic Law (Cambridge: Cambridge University Press, 2008).

UNICEF, 'Tunisia Mena Gender Equality Profile Status of Girls and Women in the Middle East and North Africa,' available at http://www.unicef. org/gender/files/tunisia-Gender-Equality-Profile-2011.pdf, accessed on 12 May 2018.

Ur-Rahman A, Code of Muslim Personal Law, vol. 1 (Karachi: Islamic Publishers, 1984).

Voorhoeve, 'Judicial Discretion in Tunisian Personal Status Law,' in Family Law in Islam: Divorce, Marriage and Women in the Muslim World (London: Taurus, 2012), 1-35.

Warren, 'Lifting the Veil: Women and Islamic Law,' Cordoza Journal of Law and Gender, vol. 15 (2008): 33-65. 
Weideman, 'Tahar Haddad After Bourguiba and Bin Ali: A Reformist between Seuclarists and Islamistst,' International Journal Middle Eastern Studies, vol. 48 (2016): 47-65.

Welchman, Women and Muslim Family Laws in Arab States: A Comparative Overview of Textual Development and Advocacy (Amsterdam: Amsterdam University Press, 2007).

Western, 'Islamic Purse Strings: The Key to the Amelioration of Women's Legal Rights in the Middle East,' Air Force Law Review (2008): 79-147.

Yusuf Ali A., The Holy Quran: Text, Translations and Commentary (Lahore: Ashraf Press, 1938).

Zoglin, 'Morocco's Family Code: Improving Equality for Women,' Human Rights Quarterly, vol. 31/4 (2009): 964-984.

\section{Statutes}

\section{Morocco}

Constitution of Morocco 1962

Constitution of Morocco 1970

Constitution of Morocco 1972

Constitution of Morocco 1996

Constitution of Morocco 2011

\section{Tunisia}

Amendment to the Constitution of Tunisia of 1988

Amendment to the Constitution of Tunisia of 1997

Amendment to the Constitution of Tunisia of 2002

Draft Constitution of Tunisia 2012

The Tunisian Constitution of 2014

The Tunisian Constitution of 2014

\section{South Africa}

Constitution of the Republic of South Africa 1996 
Jurnal Syariah, Jil. 27, Bil. 3 (2019) 505-546

\section{FOREIGN JURISDICTIONS}

Morocco

Code of Personal Status 1958

Code of Personal Status 1993

Code of Personal Status 2004

Code of Personal Status of 1956

\section{Tunisia}

Code of Personal Status 1956

Code of Personal Status 1993

Code of Personal Status 2007 